Vol. 19(2010): 43-56.

\title{
The impact of distance to the farm compound on the options for use of the cereal plot
}

\author{
Kalvi Tamm ${ }^{1 *}$, Taavi Võsa ${ }^{1}$, Valdek Loko ${ }^{1}$, Jüri Kadaja ${ }^{1}$, Raivo Vettik ${ }^{1}$ and Jüri Olt ${ }^{2}$ \\ ${ }^{1}$ Estonian Research Institute of Agriculture, Department of Agricultural Engineering and Technology, \\ Teaduse 13, 75501 Saku,Estonia,*email: kalvi.tamm@neti.ee \\ ${ }^{2}$ Estonian University of Life Sciences, Institute of Technology, Kreutzwaldi 56, Tartu 51014, Estonia
}

\begin{abstract}
In increasingly competitive conditions, the dominant trend of enlarging the production area of farms is causing a growth in transportation costs making the profitability of cultivating distant plots questionable. The aim of this study was to provide a method to evaluate the rationality of using a plot depending on its distance, area and cultivation technology. An algorithm and a mathematical model were composed to calculate the total costs depending on the distance to the plot. The transportation costs of machines and materials, cost of organisational travel and timeliness costs are taken into account in the model to enable determination of the maximum distance or the minimum area of the plot necessary for profitable cultivation.

Simulations allow us to conclude that the growth in yield and selling price of the production allow an increase in the limit value of driving costs and, thus, the profitable distance of the plot; on the other hand, it means also an increase of timeliness costs as a limitation for extending distance. Exploitation of more distant plots can be uneconomical in coming years because of increasing fuel costs.
\end{abstract}

Key-words: farm size, plot, distance travelled, intrafarm transport, transport costs, timeliness, economic evaluation, technology, mathematical models, simulation.

\section{Introduction}

Under the conditions of growing competition, the trend towards enlarging the production area of farms is dominating, causing longer driving distances to the plots. During the years 2001-2007, the portion of farms of less than 50 ha decreased; those of over 100 ha increased in the total area of agricultural land in Estonia (Fig. 1). We can observe similar trends elsewhere in the world, for example, in the USA (Schnitkey 2005), Finland (Suomi et al. 2003), England (Burton and Walford 2005), and Hungary (Burger 2001). 
Tamm, K. et al. The impact of the plot distance

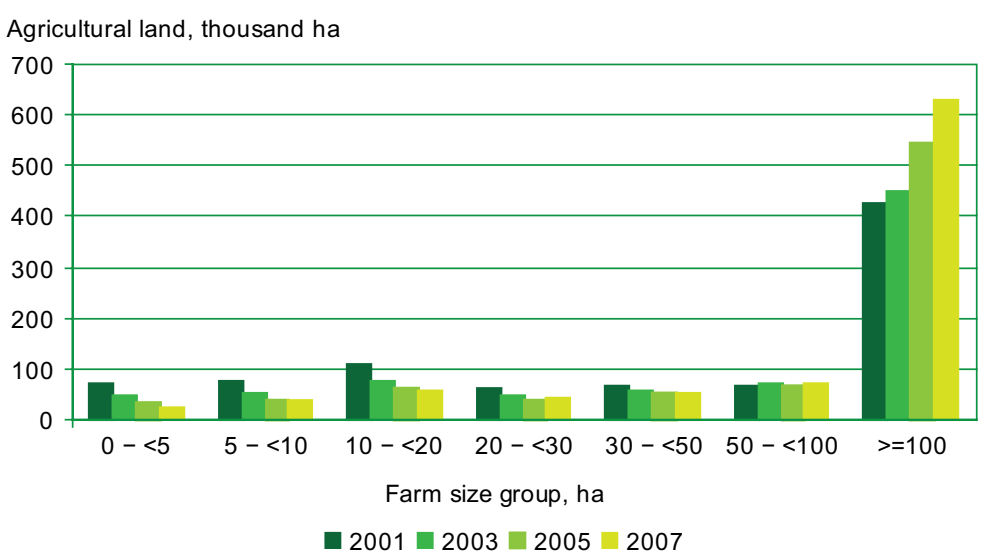

Fig. 1. Division of agricultural land according to farm sizes in years 2001-2007 (Statistics Estonia, 2009).
Farmers buy or rent land primarily to increase profitability of their enterprises (Gwyer et al. 2005), but expanded production tends to have an influence on expenses as well as on income. Enlargement of arable land enables increased effectiveness of machinery use, and in the case of constant machinery equipment, the fixed costs per hectare are decreasing. However, it may cause an increase of the costs for maintenance and repair of the machines.

In 2007 in Estonia there were 23257 farms with an average agricultural area of 39 ha; of those larger than 100 ha, 1549 farms have an average area of 405 ha. The number of plots by plots size group is given in Table 1. Aaltonen et al. (1999) reports that most plots are situated closer than 3.7 $\mathrm{km}$ to the farm compound in the EU and $6.6 \mathrm{~km}$ in Finland. There are no similar statistics for Estonia; studies are needed.

The enlargement of production area influences the portion of transportation expenses in the cost price of the yield. Along with increasing distances, transportation expenses are growing as well (Steinsholt 1997) and, in certain conditions, may exceed the increase of the income created by enlarging of production area; as a result, profitability of the farm begins to decline.

The need for increasing the effectiveness of exploitation of land and problems related to the growing costs of energy, labour and other production resources, are calling for the creation of decision support systems that analyse and plan agricultural production. Several researchers have suggested
Table 1. The number of plots depending on plot size group in Estonia by register of area supports of Estonian Agricultural Registers and Information Board in year 2008.

\begin{tabular}{lccc}
\hline $\begin{array}{l}\text { Plot size } \\
\text { group }\end{array}$ & $\begin{array}{c}\text { Number of } \\
\text { declared plots }\end{array}$ & $\begin{array}{r}\text { Declared } \\
\text { area, ha }\end{array}$ & $\begin{array}{c}\text { Average plot } \\
\text { area, ha }\end{array}$ \\
\hline$<1$ ha & 46339 & 24333 & 0.53 \\
$1-<5$ ha & 61570 & 160791 & 2.61 \\
$5-<10$ ha & 23876 & 173126 & 7.25 \\
$10-<50$ ha & 23331 & 447576 & 19.18 \\
$50-<100$ ha & 951 & 61840 & 65.03 \\
$100<$ & 90 & 12635 & 140.39 \\
Total & 156157 & 880301 & 5.64 \\
\hline
\end{tabular}

(Bouma et al. 1998) the need for composing a method that would assist determining optimal farm size. Mathematical modeling is an essential method here. In the late 1990s, a research team modelling the agricultural production from the Estonian University of Agriculture composed a method to calculate the effect of the area of a round-shaped farm to the farm's profitability (Asi et al. 1999). Kryachkov and Sharova (2005) studied the optimal area of farms in the region of Kursk (Russia), determining factors to prognosticate the transportation costs depending on the area of the given agricultural enterprise. A mathematical model was presented 
Vol. 19(2010): 43-56.

to calculate the profitability of the proposed farm depending on its production capacity.

The aim of these studies was to compose a method for determining the optimal size of a farm. Nevertheless, using this parameter in real-life management of production is questionable. Should the farmer exclude from production the plots located outside the critical distance, i.e., sell or lease them, and seize the plots located in the vicinity, i.e., buy or rent them? In reality, individual plots have individual properties, different crops, and, thus, different operational capacities and production costs (Jabarin and Epplin 1994, Harasimowicz and Ostršgowska 2001). One critical factor is the size of the plot. Introduction of a small plot located far away from the farm compound will probably not be economical as the transportation costs will be so high that the production will not be profitable. This may also be true for plots remaining inside the critical border. For planning of production, therefore, a method is required to analyse the costs taking into account the distance, the area and the cultivation technology used there.

In an overview of studies in the field of agrologistics, Hahn (2006) denotes that theory-forming contributions to the mentioned research area are still rare in literature. Morlon and Trouche (2005) also find that there is scarcely relevant scientific literature available and the existing materials are generally based on ancient or simplistic schemes and models which are not of practical use in the present conditions.

There are, however, references to studies in which distances inside the farm are used as one of the problematical factors of plant production. One of the first contributions in that area was worked out by Johann Hermann von Thünen (1783-1850), who developed the model to describe the land use practices radiating out from a central market location (Crosier 2009). He theorized that several rings of agricultural land use practices would surround the central market place. The land within the closest ring around the market produces products that are profitable in the market, yet are perishable or difficult to transport. As the distance from the central market increases, the land use shifts to producing products that are less profitable in the market, yet are much easier to transport. The general approach of von Thünen illustrated the use of distance-based gradient analysis (e.g., the change in value for a variable such as land rent with increasing distance from the city center).

De Garis De Lisle (1982) has studied the effects of intra-farm distance on farm income and on internal cropping patterns. The research was based on the data of the farms situated in Manitoba (Canada) collected by crop insurance agents. The following conclusions were drawn: 1) the distribution of crops is affected both by the distance of the plot to the farm compound and the soil productivity; 2) adjustments to the organization and intensity of farming compensate the effects of distance on the net income.

Myyrä and Pietola (2002) estimated with the help of a switching-type Probit-model the shadow prices for land parcel characteristics in Finland, such as size and distance from the compound, by adding these characteristics to the conditional profit maximization model. Their research concludes that plot size and distances from the farm compound significantly affect the farmer's choice of allocating most of the land either to grass or to grain. Harasimowicz (1997) describes an evaluation system, where plot distance to the compound is one factor affecting land value in points characterising the profitability potential of land: a plot situated far away is assessed to be less valuable than a closer one.

The literature overview indicates that there is no research available containing a method to estimate rationality for exploitation of the plot based on the distance between plot and farm compound. The aim of this study is to compose a mathematical model to calculate these costs and thereby estimate the rationality of exploitation of a plot on the basis of driving distance. The model considers transportation costs of aggregates, hauling costs of materials, income loss caused by delays in field work, and the cost of organizational drives. All the factors influencing technology, like crop (Fig. 2), machines or technological materials can be considered with choice of technology. The present model considers the cereals seedbed preparation and sowing operations' influence on the income loss. 
Tamm, K. et al. The impact of the plot distance

On the basis of the model, software "Field distance" is composed, enabling, in a relatively short period of time, evaluation of the rationality of using different technologies on a particular plot depending on its area and distance.

The paper gives an overview of the composed model and its practical use with different tillage technologies. The simulations are used to estimate the influence of the price of fuel and yield, as well as the yield level on the economical maximum of plot distance.

\section{The model}

Economical parameters depending on plot distance Following the aim of composing the mathematical model for evaluating the rationality of exploitation of a plot taking into account the driving distance, we concentrated on the economical parameters depending on that factor. The expenditures arising from distance were separated from other production costs; these are the costs related to the transportation of the field aggregates and the technological materials, and the costs of all organizational trips to the plot (Tamm 2006). In addition to the expenses, we need to look at the effect of driving distance on income. If the distance increases, the daily performance of the field aggregate will decrease and work periods will lengthen; as a result, the working time will increasingly deviate from the optimal and the average yield will decrease. The consequent income loss is considered a cost, as well. Thus:

$$
K_{h}=K_{s}+K_{v}+K_{o}+\Delta T
$$

where $K_{h}$ is the sum of costs depending on distance to the plot $\left(€ \mathrm{ha}^{-1}\right), K_{s}$ is the driving cost of aggregate to and from the plot for one production year $\left(€\right.$ ha $^{-}$ $\left.{ }^{1}\right), K_{v}$ is the cost of hauling the materials to or from the plot $\left(€ \mathrm{ha}^{-1}\right), K_{o}$ is the driving cost of service vehicles per one production year $\left(€ \mathrm{ha}^{-1}\right)$, and $\Delta T$ is the income loss caused by driving duration $\left(€ \mathrm{ha}^{-1}\right)$.
The evaluation of options of exploitation of the plot Using a plot within a certain distance is rational in cases when the cost $K_{h}$ related to distance is less than the maximum value $K_{h, \max }\left(K_{h} \leq K_{h, \text { max }}\right)$. The last one is found with formula

$$
K_{h, \max }=T-K_{m}
$$

where $T$ is predicted income ( $€ \mathrm{ha}^{-1}$ ) and $K_{m}$ are the costs independent of distance $\left(€ \mathrm{ha}^{-1}\right)$. If the model user wants take into account the profit or the production risk, these factors can be added to $K_{m}$.

In order to determine the economically reasonable maximum distance between farm compound and the plot considering its area and technology, the distance in the case of $K_{h, \max }$ must be found. While the distance cannot be analytically found by the system of formulas composed for calculating $K_{h}$, then the iterative method is used. The method enables finding the distance in which the sum of the costs is the nearest to the limit value. i.e., $K_{h} \rightarrow$ $K_{h, \max }$. The plot area and the technology are fixed while seeking distance $d$. In the case of the iterative method, it is necessary to define the tolerance $\delta$; when it has been achieved, the calculation procedure will be completed. In other words, the following condition should be fulfilled:

$$
\left|K_{h}-K_{h, \max }\right| \leq \delta
$$

If the condition (3) is met, then the distance used for finding the parameter $K_{h}$ is the economically reasonable maximum distance between the farm compound and the plot, considering its area and technology.

There are three phases of the iterative method: we used the determination of the initial solution, the secant method (Weisstein 2006a) and bisectioning (Weisstein 2006b). The calculations thus far show that the 50 cycles are enough to reach a satisfying solution. After having tested the model, the following schema is composed to search solution: 1) 1st Cycle - calculating the initial solution, 2) $2^{\text {nd }}-5^{\text {th }}$ Cycle - secant method, and 3 ) $6^{\text {th }}-50^{\text {th }}$ Cycle - method of bisecting of interval.

That mathematical construction also enables the search for minimum area of plot at known 
Vol. 19(2010): 43-56.

distance. The machines would still drive back and forth at least once even for a tiny plot. Thus the farmer has transportation costs, independent of plot size. However, the plot can be so small that the income does not cover the transportation costs, especially when the distance is long. It means that $K_{h}>K_{h, \max }-$ the transportation costs are larger than the amount of money available for transportation expenses. The larger the plot, the smaller the transportation costs per ha (costs are divided with the area) unless two trips are made - then the sum of transportation costs per ha jerk upward and then start to decrease again, etc. (Fig. 4). If the market conditions are favourable for the farmer, then with increasing the plot size the income for the whole plot grows faster than costs; at some point, the value of the area is $K_{h}<K_{h, \max }$. The condition $K_{h}=K_{h, \max }$ is the indicator that shows the minimum value of a plot area.

The minimum area of the plot is calculated with the same algorithm as for maximum distance. The difference is that initially a value for distance $d$ is fixed, and thereafter the minimum plot area is searched by the certain value of the limit cost $K_{h, \max }$. If the distance is relatively long and the value of limit cost is relatively small, it is possible that the minimum area of the plot cannot to be determined.

The overview of the model for calculating costs depending on driving distance

In the present study, the driving distance to the plot denotes the shortest way passable with an agricultural machine from farm compound to nearest entry point in the plot. The farm compound is the storage location for most of the farm's field machines and technological materials.

In the process of composing a calculation model, all technology/technical equipment used during the whole yield year on the plot is taken into account (Fig. 2).

The model incorporates four components: the cost of transport of machines, the cost of hauling materials, the cost related to organisational drives, and the income loss arising from timeliness of seedbed preparation and sowing operations (Tamm 2006).
While calculating the transportation costs, it is considered that a task can be performed with several different aggregates and during numerous work days. It is presumed that the operator returns with an aggregate to the farm compound at the end of the work day. The calculation schema for transportation costs is based on the hourly cost of idle drive of aggregate considering expenses related to the machines in transit (Hunt 2001, Witney 1988).

In the case of hauling materials, it is considered that several hauling cycles and numerous vehicles can be used for moving one type of material. The materials are differentiated by the class of the payload usage of transporters and this defines the factor of the payload usage of the wagon (ATK 1984). The calculation schema of hauling cost is based on the price of a driving hour of the vehicle, which is computed considering fuel consumption dependency on the machine load in different phases of the transportation cycle (Grisso et al 2006).

It is presumed by composing the calculation schema of costs related to organisational drives that the vehicle load undergoes no significant change during the entire trip. Required information includes the count of one vehicle driving during the whole yield year as well as the average speed and price per driving hour of the given machine.

The relationship between income and plot distance is based on studies (Giunta et al. 2007, Haller 1969, Karmin 1975, Toro 2005) indicating that yield depends on the calendar time (days) of performing field operations:

$$
h_{t}=h_{\max }\left(1-b t^{2}\right)
$$

where $h_{t}$ is yield from farm area, seeded in day $t$ $\left(\mathrm{kg} \mathrm{ha}^{-1}\right), h_{\max }$ is yield from farm area, seeded in the best day (highest yield), $b$ is regression coefficient related to the yield loss per sowing day $\left(\right.$ day $\left.^{-2}\right)$ and $t$ is number of days deviating from the optimal sowing day.

The longer the distance, the greater part of the workday is spent on driving to and from the plot. However, at the same time, hours available for work on the plot decreases, and thus the number of workdays necessary to perform the work on the plot increases. With a higher number of workdays, 
Tamm, K. et al. The impact of the plot distance

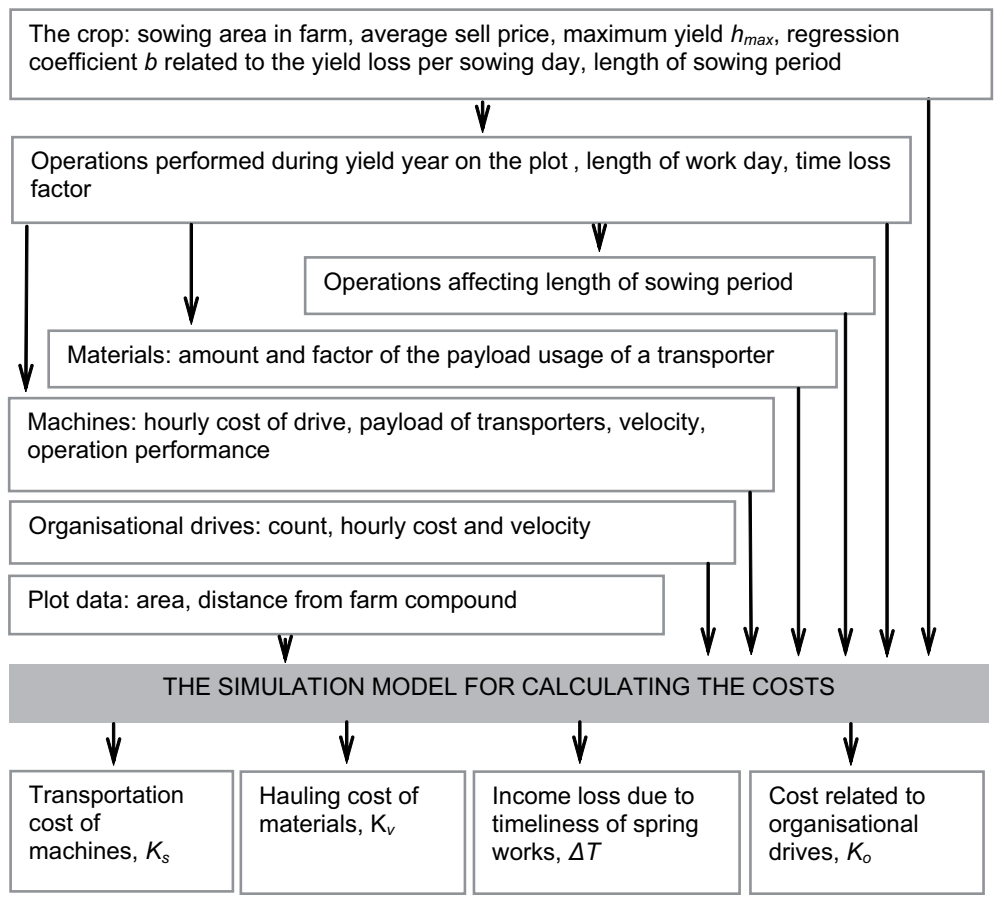

Fig. 2. The calculation model for calculating costs depending on driving distance, the inputs and outputs of the model an increase of deviation from the best working time is accompanied by a decrease of average yield. Profound research exists about relations of timeliness of sowing in Estonia (Tamm 1999), thus the model takes into account the knowledge of how timeliness is affected by the duration of transporting seedbed preparation aggregates and sowing aggregates.

\section{Data used in simulations}

The data chosen for the simulations were previously used in the calculations for economical comparison of different pre-sowing tillage and sowing technologies (direct drilling, conventional and minimum tillage) (Loko and Tamm 2004). In the calculations, for the purpose of simplification, it is assumed that all travels related to the plot start from the farm compound. To determine the number of working hours of the farm machines, it is taken into account that the farm has 450 ha of arable land with $75 \%$ under the spring cereals and $25 \%$ under the winter cereals.

The present calculations are made for spring cereal plots, which account for the largest portion of
Estonian farming area. Although it was presumed that $25 \%$ of cereal area is under winter cereals, that does not affect the sowing period of spring cereals. The model presumes that formula 4 suits other crops as well. This is a widely used formula for calculating timeliness costs for crops (Witney 1988). Table 2 shows values of regression coefficient $b$ for cereals if delay from best sowing time is $1-15$ days.

Table 2. Value of regression coefficient $b$ for cereals, if delay from best sowing time is 1-15 days (Tamm 1999).

\begin{tabular}{lcc}
\hline Cereal & $\begin{array}{c}\text { Regression } \\
\text { coefficient } b\end{array}$ & $\begin{array}{c}\text { Variability with 95\% } \\
\text { probability }\end{array}$ \\
\hline Spring barley & 0.00117 & $0.00105-0.00129$ \\
Oat & 0.00107 & $0.00080-0.00134$ \\
Spring wheat & 0.00120 & $0.00095-0.00145$ \\
Winter rye & 0.00203 & $0.00164-0.00242$ \\
Winter wheat & 0.00170 & $0.00125-0.00215$ \\
\hline
\end{tabular}


Vol. 19(2010): 43-56.

The operation performances and hourly work costs of aggregates depend on tractors (Table 3). There are two tractors among the machinery, with the engine power of $100 \mathrm{~kW}$ and $75 \mathrm{~kW}$ (T1 and $\mathrm{T} 2$ in tables). The fuel price $0.69 € 1^{-1}$ serves as the basis for calculating the hourly costs. In all variations, the length of working day at value $T_{t}=8 \mathrm{~h}$ and time loss factor $\tau=0.85$ are considered. These factors influence the number of workdays and trips to the plot.

The software "Field distance" was programmed using developer software Microsoft Visual FoxPro 8.0 and includes both the calculation models needed for calculating the costs related to the driving distance as well as the algorithms for determining the maximum driving distance or the minimal area of the plot. The software enables drawing different plans with different technologies and plots, to modify them, and compare the results.
The increased cost of driving hour in the case of minimum tillage and direct drilling is related to the increase of proportion of fixed costs in the hourly cost. This is a result of the decrease in the number of operations and, thus, in the yearly load of the tractor. In conventional technology, two aggregates are ploughing simultaneously and therefore the work capacity is divided according to performances. It is presumed for all three technologies that there are three spraying operations in different points in time covering the whole plot.

Data for computing transportation cost of materials is presented in Tables 4 and 5 .

Data for computing the income loss are presented in Table 6.

Definition of number of organisational drives is based on the need to evaluate the status of the plot and quality of operations (Table 7). In case of operations with low performance, such as ploughing or harvesting (Table 3), it is essential to establish fuel supply to the plot.

Table 3. Data for calculating transportation cost of aggregates.

\begin{tabular}{lccccc}
\hline Aggregate & $\begin{array}{c}\text { Speed, } \mathrm{km} \\
\mathrm{h}^{-1}\end{array}$ & $\begin{array}{c}\text { Performance, } \\
\mathrm{ha} \mathrm{h}^{-1}\end{array}$ & & \multicolumn{3}{c}{ Hourly cost of idle drive, $€ \mathrm{~h}^{-1}$} \\
\cline { 6 - 6 } & 30 & 7 & & & \\
\hline Windrower (T1) & 30 & 7 & 17.46 & 17.97 & 18.35 \\
Stubble plough (T1) & 30 & 0.9 & 14.83 & & \\
Plough (T2) & 30 & 1.1 & 17.46 & 16.05 & \\
Plough (T1) & 30 & 6 & 14.83 & 17.97 & 18.35 \\
Cultivator (T2) & 30 & 5 & 17.46 & 17.97 & \\
Drill (T1) & 30 & 5 & 17.46 & 17.97 & 18.35 \\
Harrow (T1) & 30 & 8 & 17.46 & 26.79 & 26.79 \\
3 times sprayer (T1) & 20 & 1.5 & 26.79 & & \\
Harvester & & & &
\end{tabular}

Table 4. Hourly costs and fuel consumptions of aggregates exploited for hauling of materials

\begin{tabular}{lccccc}
\hline \multirow{2}{*}{ Vehicle } & \multicolumn{2}{c}{ Hourly cost without fuel cost, $€ \mathrm{~h}^{-1}$} & & \\
\cline { 2 - 6 } & $\begin{array}{c}\text { Conventional } \\
\text { tillage }\end{array}$ & $\begin{array}{c}\text { Minimum } \\
\text { tillage }\end{array}$ & $\begin{array}{c}\text { Direct } \\
\text { drilling }\end{array}$ & $\begin{array}{c}\text { Fuel use at full load, } \\
1 \mathrm{~h}^{-1}\end{array}$ & $\begin{array}{c}\text { Fuel use at idle load, } \\
1 \mathrm{~h}^{-1}\end{array}$ \\
\hline Vehicle 1 (T1) & 21.16 & 22.44 & 23.59 & 16.5 & 11.6 \\
Vehicle 2 (T2) & 25.13 & 29.80 & 31.52 & 17.5 & 11.9 \\
Water trailer (T2) & 36.64 & 41.30 & 43.03 & 15.1 & 9.8 \\
\hline
\end{tabular}


Tamm, K. et al. The impact of the plot distance

Table 5. Data for computing transportation cost of materials

\begin{tabular}{lcccc}
\hline Material & $\begin{array}{c}\text { Amount, } \\
\mathrm{kg} \mathrm{ha}^{-1}\end{array}$ & $\begin{array}{c}\text { Factor of the } \\
\text { payload usage }\end{array}$ & $\begin{array}{c}\text { Loading performance } \\
\mathrm{th}^{-1}\end{array}$ & $\begin{array}{c}\text { Down loading performance } \\
\mathrm{t} \mathrm{h}^{-1}\end{array}$ \\
\hline Barley seed (T1) & 230 & 1 & 28 & 20 \\
NPK-fertiliser (T1) & 300 & 1 & 28 & 15 \\
Water for spraying (T2) & 300 & 1 & 40 & 20 \\
Barley yield (T1 +T2) & 4500 & 1 & 40 & 1800 \\
\hline
\end{tabular}

Table 6. Data for computing the income loss due to timeliness of spring sowing

\begin{tabular}{lc}
\hline Parameter & Value \\
\hline Farm's spring sowing area, ha & 337.5 \\
Portion of spring sowing area (including the plot observed), remaining to seed, $\%$ & 50 \\
Average sale price of spring cereal, $€ \mathrm{Mg}^{-1}$ & 180 \\
Average yield of spring cereal in best sowing day $h_{\max }, \mathrm{kg} \mathrm{ha}^{-1}$ & 4500 \\
Average regression coefficient for spring cereals $b$, day $^{-2}$ & 0.00115 \\
Length of sowing period, days & 16.6 \\
Driving time, affecting the sowing period, days & 0.167 \\
\hline
\end{tabular}

Table 7. Data for computing the cost of the organisational drives

\begin{tabular}{|c|c|c|c|c|c|c|}
\hline \multirow{2}{*}{$\begin{array}{l}\text { Reason for visiting } \\
\text { the plot }\end{array}$} & \multirow[t]{2}{*}{ Vehicle } & \multirow{2}{*}{$\begin{array}{l}\text { Hourly cost, } \\
\quad € \mathrm{~h}^{-1}\end{array}$} & \multirow{2}{*}{$\begin{array}{l}\text { Speed, } \\
\mathrm{km} \mathrm{h}^{-1}\end{array}$} & \multicolumn{3}{|c|}{ Number of plot visits } \\
\hline & & & & Conventional tillage & Minimum tillage & Direct drill \\
\hline Observations & Car & 19.18 & 60 & 10 & 9 & 7 \\
\hline Fuel supply & Fuel truck & 25.58 & 50 & 3 & 2 & 2 \\
\hline
\end{tabular}

\section{Simulations}

\section{The influence of tillage technologies}

The model was used to estimate the influence of tillage technology on the costs depending on driving distance and plot area (Table 8 and 9).

With minimum tillage, the number of operations and thus drives is smaller compared to conventional technology; these numbers are at their smallest with direct drilling. However, after calculations it became clear that differences in maximum distances to the plot are small across the different technologies compared (Fig. 3). In the case of direct drilling, the cost of transportation of machines and organisational drives is less than when using other technologies, but the cost of hauling materials is higher (Table 8). It derives from the larger portion of fixed costs in the hourly cost of the tractor, caused by the smaller number of operations performed and, consequently, less yearly work time of the tractor compared to other technologies. Many operations with low hourly cost were compared with few operations with high hourly cost. In comparison, in the high hourly cost operation, in all technologies, the machines had the same yearly work load as well as hourly cost with conventional tillage. In these circumstances, all costs, except income loss, are decreasing along with a lessening number of operations, and the differences of maximum distances of plot are somewhat more 
Vol. 19(2010): 43-56.

Table 8. Costs $\left(€ \mathrm{ha}^{-1}\right)$ depending on distance if the plot distance is $20 \mathrm{~km}$ and area is 16 ha

\begin{tabular}{lccc}
\hline Cost & Conventional tillage & Minimum tillage & Direct drill \\
\hline Transportation cost of machines $K_{s}$ & 25.38 & 20.33 & 17.71 \\
Hauling cost of materials $K_{v}$ & 32.21 & 34.84 & 36.24 \\
Income loss due to yield recession, $\Delta T$ & 18.09 & 18.09 & 18.09 \\
Cost of organisational drives $K_{o}$ & 12.98 & 10.74 & 8.95 \\
Total costs $K_{h}$ & 88.65 & 83.99 & 80.98 \\
\hline
\end{tabular}

notable (Fig. 4) than in the case of unlike yearly workload. For example, for conventional tillage, minimum tillage and direct drill on the 30 ha plot in the case of different workloads, the maximum distances are, respectively, 17.9, 18.7, and $19.2 \mathrm{~km}$. With similar workload, these distances are 17.9, 19.4 and $20.4 \mathrm{~km}$.

Depending on the plot area, the maximum distance changes by fixed $K_{h, \max }$ at the beginning almost proportionally until the approximate plot area of 15 ha. From then on, the growth is slowing down slightly, but continues intensively until plot area of 20 ha; after that, the distance value will approximate asymptotically to some limit value. In economic conditions typical for Estonia, which date for this study approximates, the economical maximum distance for larger plots falls within the interval of $18-25 \mathrm{~km}$. The jerks on the graphs (Fig. 3 and 4) are caused by the changes in the number of the driving times related to the specific work or hauling material. For example in the case of the 28 ha plot area, the sowing aggregate would be transported to the plot on two workdays, doubling the driving time, resulting in a sharp growth in income loss per hectare. However, while the total value of costs is limited, the other costs should decrease accordingly and it will result in the need for shorter distance (Fig. 5). Although the cost related to the transport of sowing aggregate is increasing, then a decrease in transportation cost of other aggregates due to shortening the distance is sufficient to slightly decrease the total transportation cost of aggregates.
Table 9. Cost $\left(€ \mathrm{ha}^{-1}\right)$ depending on plot distance and area in case of conventional technology

\begin{tabular}{lrrr}
\hline Distance & \multicolumn{3}{c}{ Transportation cost $K_{h}, €$ ha $^{-1}$} \\
\cline { 2 - 4 } & 10 ha & 15 ha & 20 ha \\
\hline $10 \mathrm{~km}$ & 58.85 & 44.41 & 38.80 \\
$20 \mathrm{~km}$ & 117.96 & 89.00 & 77.76 \\
$30 \mathrm{~km}$ & 176.90 & 138.85 & 117.50 \\
\hline
\end{tabular}

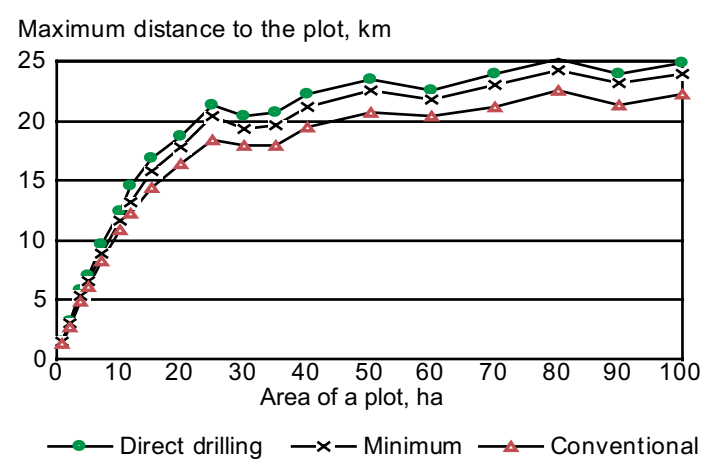

Fig. 3.The maximum plot distance dependency on plot area in the case of different tillage technologies if costs depending on the distance should not exceed $64 € \mathrm{ha}^{-1}$. The yearly workload of machines depends on the technology

\section{The influence of fuel price}

In order to examine the influence of the fuel price, conventional tillage technology was simulated and hourly prices of machines were computed for three fuel price levels (Fig. 6). 


\section{AGRICULTURAL AND FOOD SCIENCE}

Tamm, K. et al. The impact of the plot distance

In Estonia, the special purpose diesel fuel can be used in agricultural production; this diesel fuel has fewer excises than paid by ordinary consumers. The excises on special purpose diesel fuel began to rise early in 2008, increasing the fuel price from about 0.57 to $0.69 € 1^{-1}$. The third price level is established on the prediction that farmer will use the fuel priced for the ordinary consumer, $0.96 €$ $1^{-1}$. If the plot area enlarges, then the fuel price affects the maximum distance of the plot until certain value - in the present case approximately until 25 $\mathrm{km}$; after that the differences of distances for unlike price levels remain roughly the same. For example, for a plot area $30 \mathrm{ha}$, the maximum distances are $18.7,17.9$ and $16.2 \mathrm{~km}$ from the lowest to the highest price level. Therefore, the higher the fuel price, the more the farmer must think about the rationality of exploitation of distant plots. Consequently, there exists the danger that a plot located in the distance that has provided profitable production in the past, is becoming unprofitable due to rising fuel prices. In Estonia, it has already occurred in 2008 because of the increase in fuel prices.

High fuel price can also hinder farm size. The greater the fuel price the higher are field operation and transportation costs, and increased operation costs decreases available funding for transpor-

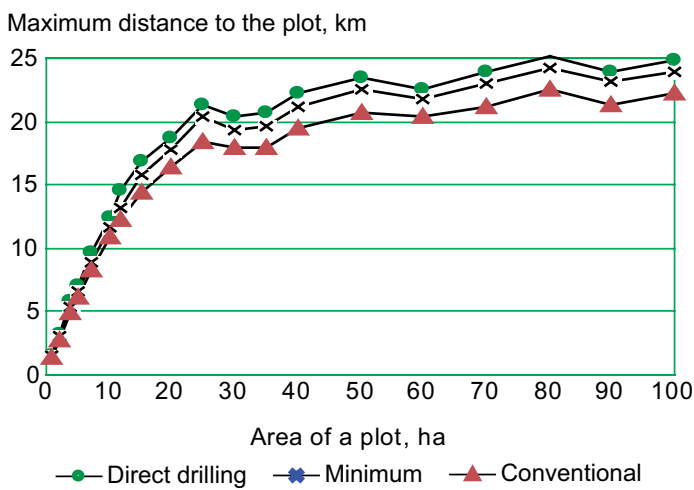

Fig. 4. The maximum plot distance dependency on plot area in the case of different tillage technologies if costs depending on the distance should not exceed $64 € \mathrm{ha}^{-1}$. The yearly workload of machines are for all technologies same as in conventional tillage. tation. Accordingly the fuel price has a doubly damaging effect on the economically reasonable transportation distances. Thus at a certain point, fuel cost can limit maximum distance to the plot, regardless of plot size, cultivation technology or choice of crop.

\section{The influence of the grain price and yield}

The grain price and yield influence the income obtained from a plot and thus the limit value reached by its costs $K_{h, \max }$ depending on the distance. The limit value of the costs affects the maximum distance of the plot significantly (Fig.7). In the present simulation with a 30 ha plot, using limit values of 100,64 and $50 € \mathrm{ha}^{-1}$, the maximum distances are, respectively, $27.3,17.9$ and $14.1 \mathrm{~km}$. Raising the limit value by $50 € \mathrm{ha}^{-1}$ allows use of a plot located within the next $13 \mathrm{~km}$ range.

On the other hand, due to increasing selling price and yield, the income loss increases with every delayed sowing day (Tamm 2006) (Fig. 8 and 9). Thus the opportune performance of sowing operations and minimising of driving time is more important for plots with high yield potential than for those with poorer soil properties: the drill must be transported to the high yield plot as fast as possible and the plot seeded without intermediate

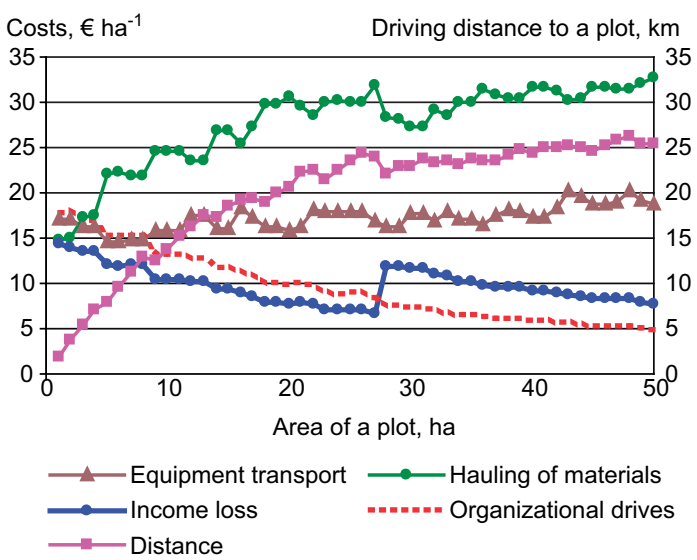

Fig. 5. The maximum plot distance and costs dependency on plot area in case of conventional technology. The costs depending on the distance should not exceed $64 € \mathrm{ha}^{-1}$. 
Vol. 19(2010): 43-56.

drives to the farm compound. One of the future tasks would be to clarify which conditions would be most rational: to return with the application aggregate to the farm compound after the work day, leave the aggregate near the plot, or perform the operation with several consecutive shifts. We plan to supplement the model with algorithms to calculate the income loss due to transportation time for machines other than the sowing aggregate.

The present model does not consider the soil type. The soil type influences the germinating environment of seed (Haller 1969). The optimal sowing time for spring cereals on heavier soils is shorter than average (EVP 1992), meaning that yield loss for every delayed day is greater for heavy soil than for light; in this case, the regression coefficient $b$ the value nearer to the higher limit of variability should be chosen (Table 2). However, the model can be supplemented by considering the type of soil, as soon as the values for correction factor depending on soil type are available.

\section{Discussion about options for using plots depending on distance}

There are several studies (De Garis de Lisle 1982, Myyrä and Pietola 2002) researching choices of crop mix affected by plot structure. Cereal crops are less expensive to transport than intensive crops such as potato, therefore it is more economical to include more cereals in arable land that is farther from the compound. A similar pattern was shown in the $19^{\text {th }}$ century by von Thünen (Crosier 2009).

In the present model the loss of yield and income depend upon the crop. There are different timeliness factors (regression coefficient $b$ in the table 2) for spring and winter cereals. Winter cereals are more sensitive to a delay of sowing time than spring cereals. Distant cereal plots increase transportation time; that, in turn, lengthens the sowing period. A prolonged sowing period decreases average crop yield, therefore, winter cereals should be cultivated closer to the farm compound than spring cereals.

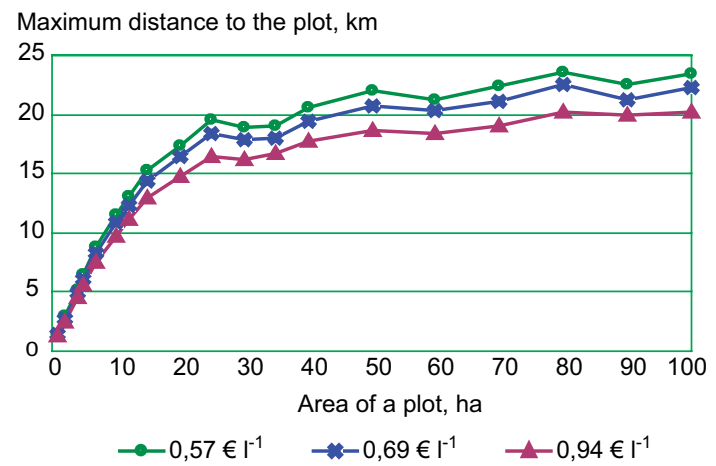

Fig. 6.The maximum plot distance dependency on plot area using different fuel prices. The costs depending on the distance should not exceed $64 € \mathrm{ha}^{-1}$.

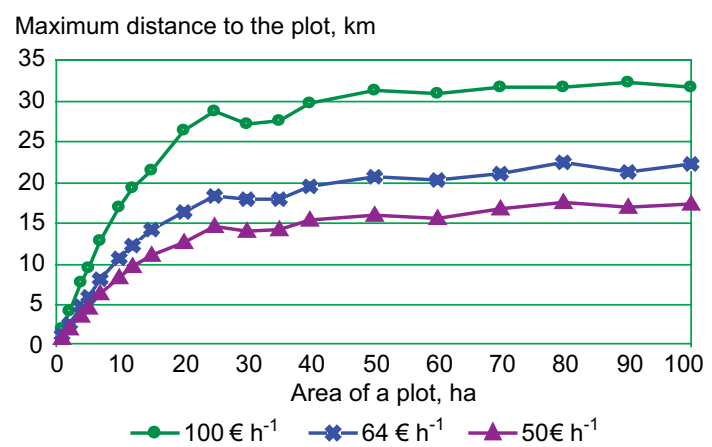

Fig. 7. The maximum plot distance dependency on field area in the case of conventional technology if the costs depending on the distance should not exceed 50,64 and $100 €$ ha $^{-1}$.

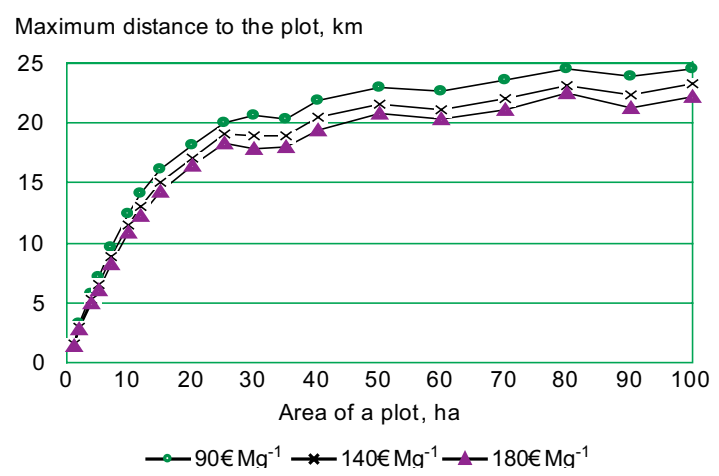

Fig. 8. The maximum plot distance dependency on plot area in the case of unlike grain prices. The costs depending on the distance should not exceed $64 € \mathrm{ha}^{-1}$ and grain yield is $4500 \mathrm{~kg} \mathrm{ha}^{-1}$. 
Tamm, K. et al. The impact of the plot distance

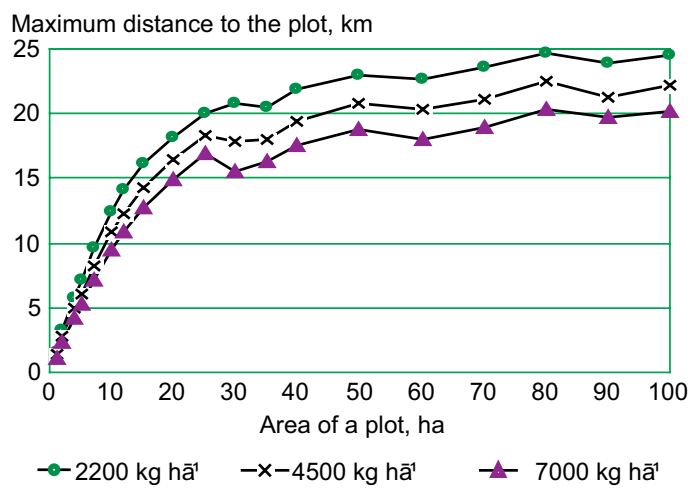

Figure 9. The maximum field distance dependency on plot area in case of unlike grain yields. The costs depending on the distance should not exceed $64 € \mathrm{ha}^{-1}$ and grain price is $180 € \mathrm{Mg}^{-1}$

Secondly often manure is used for fertilising the winter cereals. When distance is a factor, this can be significant in the choice of plots for cereal. Transportation of manure is expensive compared to mineral fertilisers (Tamm and Vettik 2007) and plots near the manure pile should be chosen for winter cereals. This approach - using mineral fertilisers instead of manure on distant plots - can be an economical solution for other crops as well (Tamm and Vettik 2008).

In the calculations the plot structure was fixed on $75 \%$ for spring cereals and $25 \%$ for winter cereals. If the portion of winter cereals is bigger it is likely that more distant plots will be chosen because of lack of suitable plots near the farm compound. However, that can lead to a decrease in average yield per hectare of winter cereals. On the other hand, the average yield of winter cereals is generally higher than spring cereals (Older 1999): total yield of cereals can be increased by increasing the area of winter cereals.

As shown in the results the economical maximum distance to plot is comparative to size of that plot. Therefore it is rational to consolidate distant smaller plots or to use the same cultivation technology on neighbouring plots to consolidate work and eliminate trips to the farm compound. The model can evaluate that approach by using the sum of adjoining plot areas.
There are other possibilities for maximizing the use of small, distant plots: some farmers rent them out to other land users, or arrange for exchanging plots with an adjacent farmer. A completely different land use is a possibility, e.g. creating a feeding area for wild animals to develop hunting tourism. However if fuel costs are high, potential income from yield is low; it may be economically wise to let small distant fields lie fallow. The bigger the input (fuel, fertilizer, labour, etc) costs, and the smaller the yield, the more likely it is that the fallow area will be increased in size. Without alternative options, however, and if the land tax is economically onerous, selling the plot is may be the best solution. At the same time, it is rational to embrace production of plots near the farm compound: rent or buy them, or turn the non-agricultural land usage to agricultural if crop production conditions are suitable.

Given the many factors to be considered to make farming economically sustainable, decision support systems are necessary. The present model is developed to support the farmer in her/his decisions regarding choice of plot for cereal cultivation considering distance, plot area and technology used on that plot. Various scenarios, market and production conditions can be substituted in the calculations.

\section{Conclusions}

The methods of agrologistical analysis facilitate evaluation of the role of transportation distance in the production results of an agricultural enterprise. Information from the studies of the influence of the plot distance on the profit potential of the plot can assist farmers' decisions about employing different cultivation technologies. The method presented in this study enables farmers to estimate the options of using a particular technology depending on the size and distance of the plot as well as to determine the maximum value of the distance or minimum value of the plot size. The calculation method presented in this paper is realised in software. One can con- 
Vol. 19(2010): 43-56.

sider plot distance and area while making decisions about the usage of arable land and thus support the competitiveness of the farm.

On the basis of the calculations performed by means of the model, it can be concluded that the economically profitable distance grows proportionally with plot size. Under the present Estonian economical conditions, in the farm with an average yield level, the increase in maximum plot distance continues until the plot area reaches 20 ha, with larger plot sizes the distance remains in the interval $18-25 \mathrm{~km}$.

The results of the simulations show that tillage technology has more influence on the maximum distance when yearly workloads of machines are equal in all technologies, as compared to the case when the workload depends on technology. The calculation outcomes also show that the prognosticated price of fuel must be taken into account when making plot-related decisions. Using distant plots that have been cost-effective until now may become unprofitable due to higher fuel cost. Larger yield or selling price of production are increasing the limit value of costs and, thus, increasing the profitable distance of the plot; on the other hand, the income losses are increasing due to timeliness of operations, lessening the tendency to increase distance.

The composed model needs further elaboration. Today, the model considers only the sowing works influence on the income loss related to driving distance, but in the future the model needs to be complemented with other operations. It would also be beneficial to create the possibility to evaluate which conditions would be most rational: to return to the farm compound with the application aggregate after the work day, leave it close to the plot, or perform the operation in several consecutive shifts.

\section{References}

Aaltonen, J., Järvenpää, M., Klemola E. \& Laurila, I. 1999. Viljan korjuu-, kuivaus- ja logistiikkakustannukset Suomessa. Maatalouden taloudellinen tutkimuslaitos. Selvityksiä 2/1999, 22 p. (in Finnish).
Asi, M., Möller, H., Soonets, K., Tamm, K \& Vettik, R. 1999. Optimization of crop-growing farm and its machinery park parameters. Actual tasks on agricultural engineering. Proceedings of 27. International Symposium on Agricultural Engineering Opatija, Croatia. p. 21-27.

ATK 1984. Põllumajandustööde normid. Mehhaniseeritud tööd. Eesti NSV Agrotööstuskoondise Info- ja Juurutusvalitsus, 383 p. (in Estonian).

Bouma, J., Varallyay, G. \& Batjes, N. H. 1998. Principal land use changes anticipated in Europe. Agriculture Ecosystems \& Environment 67: 103-119.

Burger, A. 2001. Agricultural development and land concentration in a central European country: a case study of Hungary. Land Use Policy 18: 259-268.

Burton, R. J. F. \& Walford, N. 2005. Multiple succession and land division on family farms in the South East of England: A counterbalance to agricultural concentration? Journal Of Rural Studies 21: 335-347.

Crosier, S. 2009. Johann-Heinrich von Thünen: Balancing Land-Use Allocation with Transport Cost By Scott Crosier. Cited 26 January 2009. Updated 1 January 2009. Available on the Internet: http://www.csiss.org/ classics/content/9.

EVP 1992. Suviteraviljad. Eesti Vabariigi Põllumajandusministeerium. Õppe-Metoodikakabinet.Tallinn, 64 p. (in Estonian).

Garis De Lisle, D. de. 1982. Effects of Distance on Cropping Patterns Internal to the Farm. Annals of the Association of American Geographers 72: 88-98.

Giunta, F., Motzo, R. \& Pruneddu, G. 2007. Trends since 1900 in the yield potential of Italian-bred durum wheat. European Journal of Agronomy 27: 12-24.

Grisso, R. D., David H. Vaughan, D.H.. \& Roberson, G. T. 2006. Method for Fuel Prediction for Specific Tractor Models. ASABE Paper No. 061089. St.Joseph, Mich.: ASABE.

Gwyer, B., King, T., McKenzie, B. \& Stothers, S. 2005. Land Expansion: Establishing Values and Options. Manitoba Agriculture, Food and Rural Initiatives. Cited 30 August 2007. Updated May 2005. Available on the Internet: http://www.gov.mb.ca/agriculture/financial/farm/ cap07s01.html

Hahn, J. 2006. Logistik. Jahrbuch Agrartechnik/Yearbook Agricultural Engineering. Band 18. VDMA Landtechnik/ VDI-MEG/ KTBL. Landwirtschaftsverlag: 52-58.

Haller, E. 1969. Idanemiskeskkonna mõju põllukultuuride saagile. Tallinn. 275 p. (in Estonian).

Harasimowicz S. \& Ostršgowska B. 2001. Influence of field extent on cultivation costs. Electronic Journal Of Polish Agricultural Universities, Environmental Development 4. Cited 25 January 2008. Available on the Internet: http://www.ejpau.media.pl/volume4/issue2/environment/art-03.pdf.

Harasimowicz S. 1997. Influence of plot and farm characteristics on the value of land. Zeszyty Naukowe Akademii Rolniczej im. H. Kollataja w Krakowie. Geodezja (Poland), no.16: 77-85.

Hunt, D. 2001. Farm power and machinery management. -10 th ed. lowa. 368 p.

Jabarin, A. S. \& Epplin, F. M. 1994. Impacts of land fragmentation on the cost of producing wheat in the rainfed region of northern Jordan. Agricultural Economics 11: 191-196. 


\section{AGRICULTURAL AND FOOD SCIENCE}

Tamm, K. et al. The impact of the plot distance

Karmin, M. 1975. Mullaharimise ja külvi kvaliteet. Tallinn: Valgus. p.118. (in Estonian).

Kryachkov, I. \& Sharova, N. 2005. Justification of optimal sizes of agricultural enterprises. Mezhdunarodnyi Sel'skokhozyaistvennyi Zhurnal, 4: 30-33.

Loko, V. \& Tamm, K. 2004. Agronomical and economical aspects of grain growing technology. Teadustööde kogumik Agronoomia 219, Tartu: 34-36. (in Estonian).

Morlon, P. \& Trouche, G. 2005. New stakes of field work logistics for annual crops in French conditions. II. The spatial organization of crops: Examples and questions. Cahiers d'études et de recherches francophones / Agricultures. 14: 305-11.

Myyrä, S. \& Pietola, K. 2002. Economic importance of parcel structure on Finnish farms. Agricultural and Food Science in Finland 11: 163-173.

Older, H. Teraviljakasvatuse käsiraamat. EV Põllumajandusministeerium. Saku 1999. 342 p. (in Estonian).

Schnitkey, G. 2005. Growth in farm size. Farm business management. Farm Economics Facts and Opinions. University of Illinois Extension. Cited 28 August 2007. Updated 25 Juny 2005. Available on the Internet: http:// www.farmdoc.uiuc.edu/manage/newsletters/fefo05_12/ fefo05_12.html.

Statistics Estonia. 2009. Agricultural land by size class and legal form of holder. Cited 25 January 2009. Updated 17 April 2008. Available on the Internet: http://www. stat.ee/agriculture.

Steinsholt, H. 1997. Calculation system for working time need at changes in field size, field shape and distance within the farm area. Informasjonsmoete $i$ Landbruksoekonomi 1997, Oslo (Norway), 4-5 Nov 1997.
Suomi, P., Lötjönen, T. \& Mikkola, H. 2003. Modelling of grain harvesting and storing. Nordic Association of Agricultural Scientists 22nd Congress, July 1-4 2003, Turku, Finland.

Tamm, K. 1999. Optimierung der Grundparameter des Getreideanbaubetriebes nach der Belastung des Maschinenparks. Eine Dissertation zur Erlangung des Magistergrades. Estnische Landwirtschaftliche Universität. Tartu. p. 76. (in Estonian).

Tamm, K. 2006. Travel distance and and field costs. Actual tasks on agricultural engineering. Proceedings of the 34. International symposium on agricultural engineering. Faculty of Agricultural University of Zagreb,Croatia: 415-425.

Tamm, K. \& Vettik, R. 2007. Distance and costs of transportation to the field if slurry is used for ferilinsing. Agronomy 2007: 155-158. (in Estonian).

Tamm, K. \& Vettik, R. 2008. Case study: Economics of spring feeding in grassland. Agronomy Research 6, Special issue: $387-396$.

Toro, A. de. 2005. Influences on timeliness costs and their variability on arable farms. Biosystems Engineering 92: 1-13.

Weisstein, E. W. 2006a. "Secant Method." From MathWorld--A Wolfram Web Resource. Cited 18 December 2007. Updated 24 March 2006. Available on the Internet: http://mathworld.wolfram.com/SecantMethod.html.

Weisstein, E. W. 2006b. "Bisection." From MathWorld - A Wolfram Web Resource. Cited 18 December 2007. Updated 1 March 2004. Available on the Internet: http:// mathworld.wolfram.com/Bisection.html .

Witney, B. 1988. Choosing and Using Farm Machines. New York. 412 p. 